\title{
Wartości edukacyjne w Miesięczniku Młodzieży Szkół Średnich Dąbrowy Górniczej „Młodzi Idą..." w dwudziestoleciu międzywojennym
}

\begin{abstract}
Miesięcznik Młodzieży Szkół Średnich Dąbrowy Górniczej „Młodzi Idą...” ukazywał się w latach 1933-1939 i był pismem wydawanym przez uczniów gimnazjów Zagłębia Dąbrowskiego. Od pierwszego numeru podkreślano piłsudczykowską ideę pisma. Ukazało się ono 19 marca, w dniu imienin Marszałka i już na karcie tytułowej składało mu hołd. Na łamach czasopisma pojawiały się często artykuły związane z Józefem Piłsudskim. Cytowano jego myśli i powiedzenia. Także w następnych numerach można odnaleźć teksty poświęcone Piłsudskiemu, szczególnie w listopadzie 1933 r. z okazji 15 rocznicy odzyskania niepodległości. Opublikowano wiersz K. Wróblównej Młodzi swemu Wodzowi ${ }^{1}$, a także tekst R. Markiewicza z Seminarium Nauczycielskiego z Dąbrowy Górniczej U progu święta 11-go listopada². W marcu 1934 r. na okładce pojawiło się zdjęcie popiersia Piłsudskiego (rzeźba ucznia z Gimnazjum im. S. Staszica w Sosnowcu), a na drugiej stronie tekst zatytułowany Wódz Narodu, w którym, odwołując się do Marszałka, autor wzywał: „Nam młodym przyświeca idea dźwignięcia Polski na wyżyny dobrobytu. Za jego wskazaniem pójdziemy naprzód! Musimy wykazać, że jesteśmy godni dźwigać na naszych barkach ten trud, podjęty przez obecne pokolenie"3. W marcu 1935 r. na stronie tytułowej ponownie umieszczono zdjęcie Piłsudskiego i poświęcono mu kolejne dwie strony pisma ${ }^{4}$. W kwietniu 1936 r. ogłoszono konkurs prac o Marszałku. Można było

* Dr, Regionalny Ośrodek Doskonalenia Nauczycieli „WOM” w Częstochowie, 42-200 Częstochowa, al. Jana Pawła II 126/130.

${ }^{1}$ K. W r ó b l ó w n a, Młodzi - swemu Wodzowi, Miesięcznik Młodzieży Szkół Średnich Dąbrowy Górniczej „Młodzi Idą” [dalej: „Młodzi Idą...”] 1933, nr 4, s. 2.

2 R. M a r k i e w i c z, U progu święta 11-go listopada, tamże, s. 3.

3 T. N e b r o j, Wódz Narodu, „Młodzi Idą...” 1934, nr 8, s. 2.

${ }^{4}$ A. A n t y p or o w i c z, Piłsudski, „Młodzi Idą...” 1935, nr 15, s. 2; M. W., 19 marca, tamże, s. 3;
\end{abstract}


zgłaszać wiersze, nowele, impresje, artykuły, wspomnienia itd., a w następnym numerze opublikowano najlepsze prace ${ }^{5}$. Piłsudskiemu i tematyce patriotycznej poświęcono numer z maja 1937 r., ukazał się w drugą rocznicę śmierci Marszałka. W słowie wstępnym do tego numeru czytamy: „Bo, oto stoi Polska solidarna i mocna, z chęcią pracy i poświęcenia, z postanowieniem uczciwym i rzetelnym, by nic nie uronić Jego wielkiej, czasem twardej, ale z najlepszego, polskiego

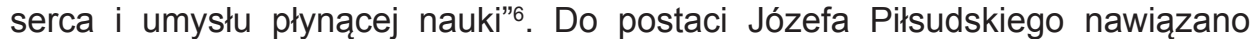
także w jubileuszowym numerze, wydanym z okazji dnia 11 listopada w 1938 r. ${ }^{7}$ Niewątpliwie myśl piłsudczykowska stanowiła profil ideowy pisma.

W miesięczniku „Młodzi Idą...” nie ograniczano się jednak do okazywania uwielbienia dla Marszałka. W nocie od redakcji czytamy: „Żyjemy w epoce, kiedy przeżywają się stare hasła, systemy i poglądy, kiedy w ciągłem zmaganiu budzą się nowe formy życia. My, młodzi, musimy również stanąć do tej walki zorganizowani i odpowiednio przygotowani. My młode pokolenie odrodzonej Ojczyzny, już w zaraniu naszego życia musimy się przygotować do przyszłych obowiązków obywatelskich w służbie Bogu, Ojczyźnie i społeczeństwu - niezbędną więc nam jest własna prasa, która by nas informowała, uczyła, urabiała opinie, kształciła charaktery i ideały. Rozpoczynając wydawnictwo naszego pisemka, będziemy dążyli do wytworzenia z każdej i z każdego z nas - dobrych obywateli państwowców, którzy by swój trud i pracę poświęcili dla dobra państwa i społeczeństwa polskiego i którzy by poczuwali się do odpowiedzialności za ich losy. Naszym celem będzie pobudzanie młodzieży do pracy społecznej, wzbudzanie w niej zainteresowań sprawami kulturalno-oświatowymi i przejawami życia polityczno-gospodarczego. Będziemy dążyć do stania się przednią strażą myśli i kultury polskiej, oddziałem kulturalnym, idącym zwarcie i konsekwentnie ku wytkniętym celom"8.

Pierwszym redaktorem naczelnym pisma był Jerzy Lis, uczeń Gimnazjum im. W. Łukasińskiego w Dąbrowie Górniczej ${ }^{9}$. Kuratorem, czyli opiekunem pisma, był prof. dr Henryk Augustyński ${ }^{10}$. Początkowo w skład komitetu redakcyjnego wchodzili uczniowie szkół z Dąbrowy Górniczej: Szkoły Handlowej, Gimnazjum im. E. Zawidzkiej, Państwowej Szkoły Górniczej i Hutniczej (PSGH), Gimnazjum Męskiego im. W. Łukasińskiego i Seminarium Nauczycielskiego. Redakcja mieściła się w Gimnazjum Męskim im. W. Łukasińskiego w Dąbrowie Górniczej. W trzecim numerze wymieniono też w komitecie redakcyjnym uczniów z Gimnazjum

Siwemu Panu w hołdzie, tamże, s. 3.

${ }^{5}$ W. S t a c he r s k i, Non omnis moriar, „Młodzi Idą...” 1936, nr 22, s. 1; Z. B u dz y ń s k i, Wizja, tamże, s. 2; S. S u p e r n a k, Tragizm wielkości, tamże, s. 3-4; D. K u c h a r s k a, Pieśń, w której nie ma śmierci, tamże, s. 5; W. Ku z i a, Pamiętam, tamże, s. 6; J. G ó r e c k i, W rocznicę, tamże, s. 7.

${ }^{6}$ F. Z., Pamięci Wodza Narodu, „Młodzi Idą” 1937, nr 29, s. 1.

7 M. R z e p k i e w i c z ó w n a, Po zwycięstwie, „Młodzi Idą” 1938, nr 37, s. 2-4.

8 Od Redakcji, „Młodzi Idą...”, 19 III 1933, nr 1, s. 2.

9 Strona tytułowa, „Młodzi Idą...”, tamże, s. 1.

10 Po wojnie, w latach 1956-1964, nauczyciel języka polskiego i dyrektor (w latach 1960-1964) II Liceum Ogólnokształcącego im. Króla Jana II Sobieskiego w Krakowie. Zob.: Spis nauczycieli oraz pracowników administracji szkolnej, służby zdrowia i woźnych III gimnazjum obecnie II Liceum im. Króla Jana III Sobieskiego w latach 1883-1983, http://www.stankiewicze.com/index.php?kat=23\&sub=595 [dostęp: 18.10.2011 r.]. 
im. W. Replińskiej w Będzinie, Gimnazjum Zgromadzenia Kupców w Będzinie. Od czwartego numeru, wydanego w listopadzie 1933 r., redaktorem naczelnym był Tadeusz Gwóźdź. Do redakcji pisma dołączyli uczniowie z Gimnazjum Męskiego w Olkuszu. Miesiąc później dołączyli uczniowie z Sosnowca: z Gimnazjum im. E. Plater, Seminarium Żeńskiego, Gimnazjum Zrzeszenia Rodzin, Gimnazjum im. S. Staszica, a także z Gimnazjum im. Kazimierza Wielkiego w Olkuszu. W szóstym numerze także z Gimnazjum im. Bolesława Prusa w Sosnowcu. Za wydanie dziesiątego numeru odpowiadało już piętnaście szkół ${ }^{11}$. Od numeru jedenastego z listopada 1934 r. redaktorem naczelnym był Jan Krommenau. W tym czasie w skład komitetu redakcyjnego wchodzili już uczniowie: Gimnazjum im. E. Plater w Sosnowcu, Seminarium Żeńskiego w Sosnowcu, Gimnazjum W. Replińskiej w Będzinie, Gimnazjum E. Zawidzkiej, Gimnazjum im. Rzadkiewiczowej, Szkoły Handlowej w Dąbrowie Górniczej, Szkoły Handlowej w Sosnowcu, Gimnazjum im. S. Wyspiańskiego, Gimnazjum im. S. Staszica, Gimnazjum Zgromadzenia Kupców, Państwowej Szkoły Górniczo-Hutniczej, Gimnazjum im. W. Łukasińskiego, Gimnazjum im. B. Prusa, Seminarium Męskiego w Dąbrowie, Szkoły Handlowej Żeńskiej p. Bojarskiej w Będzinie, Seminarium Męskiego w Sosnowcu. W 1935 r. dołączyli przedstawiciele Koedukacyjnego Gimnazjum Żydowskiego w Sosnowcu. Miesięcznik po ukazaniu się szesnastego numeru przeniesiono do sosnowieckiego gimnazjum męskiego im. St. Staszica ${ }^{12}$. Od numeru siedemnastego redaktorem naczelnym był Witold Majchrowski. W kwietniu 1936 r. (nr 21) opiekunem pisma była już dr J. Makowska, a w październiku 1936 r. (nr 23) redaktorem naczelnym został Wacław Stacherski. Kolejny numer ukazał się już jako Miesięcznik Młodzieży Szkół Średnich Zagłębia Dąbrowskiego i Liceum Handlowego w Chorzowie, ale po miesiącu wrócono do poprzedniej formuły. Od numeru z lutego 1937 r. (nr 26) redaktorem był Zbigniew Budzyński, a od listopada tego roku (nr 30) Jerzy Refler z Gimnazjum im. S. Staszica w Sosnowcu. Ostatnim redaktorem, od stycznia 1939 r., był Leonard Żyłka z Gimnazjum im. W. Łukasińskiego w Dąbrowie Górniczej, a opiekunem pisma został prof. Władysław Żytyński. W marcu 1939 r. do komitetu redakcyjnego wchodzili przedstawiciele szkół z Sosnowca (Gimnazjum im. E. Plater, Gimnazjum im. H. Rzadkiewiczowej, Szkoły Handlowej im. Królowej Jadwigi, Państwowej Szkoły Zawodowej, Szkoły Gospodarczej, Liceum Handlowego, Gimnazjum im. S. Staszica, Gimnazjum im. B. Prusa, Gimnazjum im. S. Wyspiańskiego, Gimnazjum Przemysłu Artystycznego, Liceum Pedagogicznego, Szkoły Handlowej im. Płockiego), Będzina (Szkoły Handlowej Żeńskiej, Gimnazjum im. Replińskiej, Gimnazjum im. M. Kopernika), Dąbrowy Górniczej (Gimnazjum im. Zawidzkiej, Gimnazjum Kupieckiego, Gimnazjum im. W. Łukasińskiego).

$\mathrm{Na}$ uwagę zasługuje piękna szata graficzna pisma. Pierwsze numery powstały w Drukarni "Sztuka” w Dąbrowie Górniczej, co od początku nadało pismu profesjonalny wygląd. Już w czwartym numerze pojawiła się inicjatywa,

${ }^{11}$ Redakcja mówi..., „Młodzi Idą...” 1934, nr 10, s. 16.

${ }^{12}$ W. S t a r o śc i a k, Tradycje czytelnictwa i czasopiśmiennictwa w Dąbrowie Górniczej, źródłem inspiracji Raptularza Kulturalnego, „Raptularz Kulturalny” Kwartalnik Miejskiej Biblioteki Publicznej im. Hugona Kołłątaja w Dąbrowie Górniczej 2007, nr 1, s. 11. 
aby projektami okładek zajmowali się uczniowie. Początkowo udało się to w listopadzie 1933 r., w kwietniu 1934 r., kiedy okładki były autorstwa ucznia Barczyka z Gimnazjum Męskiego w Olkuszu. W grudniu 1934 r. okładkę projektował Z. Dobrowolski, a całość odbito czcionkami Zakładów Drukarskich „Praca” w Sosnowcu. Redakcja współpracowała z tymi zakładami do 1937 r. Od marca 1935 r. przyjmowano do realizacji projekty okładek autorstwa S. Lasikiewicza. W numerze z listopada tego roku artysta malarz i grafik Wacław Pilecki na łamach pisma wyjaśniał, jak rozróżniać techniki graficzne, w tym często stosowany do ilustracji pisma linoryt ${ }^{13}$. W styczniu 1936 r. okładkę projektował i wykonywał linoryty uczeń Czerwiński, a w kwietniu E. Lewandowski, wtedy też wszystkie klisze projektowała i wykonała G. Goldówna. Zarówno Lewandowski, jak i Goldówna byli uczniami Szkoły Przemysłu Artystycznego w Sosnowcu. Szkoła ta podjęła się projektowania okładki także do numeru z listopada tego roku. Współpracę systematycznie rozszerzano. Uczennica tej szkoły, Danuta Mańkowska, projektowała okładkę w kwietniu 1937 r. W marcu tego roku zrezygnowano z wielokropka w tytule czasopisma. W październiku 1937 r. w piśmie pojawiła się informacja, że linoryty projektowała i wykonała Danuta Mańkowska, składał Stanisław Czechowski, tłoczył Marian Kula (instruktorzy Wydziału Grafiki Gimnazjum Przemysłu Artystycznego w Sosnowcu). Od tego czasu szkoła ta przejęła wydawanie miesięcznika. W listopadzie do zespołu grafików dołączyli: Stanisław Gliwa, Zygmunt Czech, Alojzy Golda, Jakób Cymbernopf. Do grudniowego numeru okładkę projektował J. Refler, a w styczniu 1938 r. Z. Styś. Oboje byli uczniami Państwowego Gimnazjum im. S. Staszica w Sosnowcu. W kwietniu ogłoszono konkurs na projekt okładki do numeru majowego ${ }^{14}$. W listopadzie projekty ilustracji i klisze wykonali uczniowie Wydziału Grafiki Szkoły Przemysłu Artystycznego: Barbara Gieroniówna, D. Mańkowska, Mieczysław Dźwigał, Henryk Hajok, Antoni Porębski, w grudniu: B. Gieroniówna, Krystyna Podsiadłówna, J. Cymberknopf, Krzysztof Papiernik i A. Porębski. Można więc powiedzieć, że pismo, poza samym faktem posiadania ciekawej szaty graficznej, dawało świetną możliwość praktycznego sprawdzenia swoich umiejętności przez młodych grafików.

Redaktorzy miesięcznika „Młodzi Idą...” często wykorzystywali rocznice i święta, aby nadać mu odpowiedni charakter. W numerze wydanym z okazji rocznicy Konstytucji 3 maja czytamy: „Czcząc entuzjastycznie pamięć Ustawy Majowej, oddajemy hołd idei, której źródłem - zbiorowy geniusz i wysiłek narodu oraz gorący patriotyzm. Konstytucja 3-go Maja była dowodem zdrowotnych sił narodu; wskrzesiła dawne ambicje państwowo-twórcze Polaków; przełamała najszkodliwsze wady przeszłości; w murze wiekowych przesądów przebiła bramę do twórczych poczynań w imię postępu i demokratyzmu"15. Do tego tematu wracano przy kolejnych rocznicach uchwalenia tej konstytucji. W 1934 r. na pierwszej stronie można było przeczytać: „3-ci maja 1791 r. Data, zapisana złotymi głoskami na najchlubniejszych kartach naszych dziejów. Data przełomowa. Dzień

\footnotetext{
${ }^{13}$ W. P i I e c k i, Kilka słów o grafice, „Młodzi Idą...” 1935, nr 18, s. 9.

14 Konkurs, „Młodzi Idą” 1938, nr 35, s. 15.

15 J. L i s, Witaj majowa Jutrzenko!..., „Młodzi Idą...” 1933, nr 2, s. 2.
} 
uchwalenia konstytucji staje nieprzebytą zaporą między Polską dawną a nową, odradzającą się. Aktem konstytucyjnym burzono gmach zdegenerowanego ustroju Polski szlacheckiej, zrywano wreszcie z przesądami, które tak fatalnie zaciążyły na losach państwa” ${ }^{16}$. Trzeci numer „Młodzi Idą...” poświęcono rocznicy odsieczy wiedeńskiej, a numer ze stycznia-lutego 1934 r. rocznicy wybuchu powstania styczniowego. Numer ze stycznia 1934 r. przypominał o powstaniu styczniowym: „71 lat minęło od chwili wybuchu powstania styczniowego. Rok przeszło toczyły się krwawe walki garstki polskich powstańców z ogromną armią rosyjską. Potem przyszła katastrofa. 5 sierpnia 1864 r. zawisł na szubienicy, na stokach Cytadeli, Romuald Traugutt, dyktator powstania, a wraz z nim poniosło śmierć czterech rzekomych członków Rządu Narodowego. Powstanie upadło. Szeregi mogił poznaczyły miejsca potyczek, do kopalń syberyjskich napłynęli nowi skazańcy, kraj pogrążył się w cichej boleści i z rozpaczą, bez wiary patrzył w przyszłość. Gwałt i przemoc zatriumfowały... [...] l dziś, gdy spokojnie zastanawiamy się nad dziejami powstania styczniowego, musimy jego uczestnikom złożyć hołd najgłębszy, mimo, że czyn ich nie miał podstaw realnych, że skończyć się musiał tragedią, że zniszczył wiele istnień. Faktem jest jednak niezbitym, że był on bohaterskim odruchem przeciw samowoli zaborcy, widomym znakiem przeogromnej miłości ojczyzny, samozaparcia i poświęcenia. Krew przelana stała się macierzystym chlebem, który wykarmił pokolenie nowe i szczęśliwsze, pokolenie bojowników o wolność narodu w czasie wojny światowej"17.

Do tematyki powstania styczniowego powrócono w 1939 r., publikując wiersz Leszka Wysznackiego Styczeń $1863^{18}$. Pozwalało to zaznajomić młodych czytelników z polską tradycją narodową i przypomnieć najważniejsze wydarzenia z historii Polski. W listopadzie 1935 r. nawoływano do pracy społecznej w szkole, która upamiętniałaby wielkie narodowe rocznice ${ }^{19}$.

$\mathrm{Na} ł a m a c h$ pisma ukazywały się artykuły w dużej mierze przygotowywane przez młodzież Zagłębia. Tematyka dotyczyła problemów społecznych, politycznych i gospodarczych. Już w pierwszym numerze ukazały się dwa artykuły autorstwa uczennic z Gimnazjum Żeńskiego im. Zawidzkiej, Hanki Piaseckiej Kobieta-Człowiek ${ }^{20}$ i Zofii Wajnsztajnówny Czytelnictwo w politycznym życiu kobiety ${ }^{21}$ poruszające problematykę równouprawnienia kobiet. Tematykę tę podejmowano jeszcze w następnych latach, np. w kwietniu 1935 r. Maria Bogdańska z Gimnazjum im. E. Plater opublikowała artykuł Znaczenie P.W.K., w którym opisała istotę i znaczenie Przysposobienia Wojskowego Kobiet. W tym samym numerze M. Wolska z Gimnazjum im. H. Radkiewiczowej napisała artykuł O twórczości poetyckiej kobiet22.

\footnotetext{
16 3-ci Maj, „Młodzi Idą...” 1934, nr 9, s. 1.

17 S. Łu bi i ń s ki, Rok 1863, tamże, nr 6-7, s. 4.

${ }^{18}$ L. W y s z n a c k i, Styczeń 1863, „Młodzi Idą” 1939, nr 39, s. 2-3.

${ }^{19}$ W. P r o c h, Dyskutujemy o pracy społecznej w szkole, „Młodzi Idą...” 1935, nr 18-19, s. 5.

${ }^{20}$ H. P i a s e c k a, Kobieta-Człowiek, „Młodzi Idą...” 1933, nr 1, s. 6.

${ }^{21}$ Z. Wa j n s z t a j n ó w n a, Czytelnictwo w politycznym życiu kobiety, tamże, s. 8.

${ }^{22}$ M. B o g d a ń s k a, Znaczenie P.W.K., „Młodzi Idą...” 1935, nr 16, s. 6; M. W o l s k a, O twórczości poetyckiej kobiet, tamże, s. 7.
} 
Uwagę zwraca sporo artykułów o tematyce morskiej czy marynistycznej, co w odległym od wybrzeża Zagłębiu Dąbrowskim mogłoby dziwić, także fakt dużej tam popularności Ligii Morskiej i Kolonialnej. Należy więc wyjaśnić, że to zainteresowanie sprawami morskimi wiązano m.in. z kwestią możliwości rozwoju gospodarczego Polski. Upatrywano szans na rozwój eksportu dla przemysłu Śląska i Zagłębia. Wyraźnie doceniano znaczenie Gdyni i Wybrzeża. W drugim numerze w wierszu L. Marszałka z PSGH zatytułowanym Morze czytamy:

\author{
Słychać jakby w borze \\ Szum tajemny gdzieś. \\ Ach! To polskie Morze \\ Niesie Polską Pieśń! \\ [...] Nie myśl Niemcze wrogi, \\ Nie waż się ni śnić, \\ Że Bałtyku progi \\ Twoje mogą być! ${ }^{23}$
}

W następnym numerze pojawiła się relacja z wycieczki do Gdyni: „I poznaliśmy pierwszą prawdziwą bajkę... - Gdynię. Nie chce się wierzyć, że przed laty miała się tu znajdować mała wioska rybacka"24.

W czwartym pojawił się bardzo mocny artykuł Zdzisława Kleindiensta ${ }^{25}$ z Gimnazjum im. W. Łukasińskiego U wrót Bałtyku pilną trzymamy straż. Czytamy w nim: „Dzisiaj, gdy nad Europą zjawiają się chmury groźnej w swych następstwach zachłanności i buty niemieckiej, gdy Niemcy występują z Ligi Narodów, nie mogąc się zgodzić na pokojowe usposobienie świata, staje się szczególnie aktualną sprawa dostępu Polski do morza, a z nim zagadnienie Prus Wschodnich. Polska zaniedbała osiągnięcie wybrzeża Bałtyku, nie wiązała z nim swojego bytu i mocarstwowego stanowiska. Dopiero teraz, kiedy widzimy w nim gwarancję potęgi państwa, bliżej się morzem interesujemy. Duży szmat nadmorskiego kraju był przez długie wieki pod naszym panowaniem, mamy do niego prawo. [...] Gdy Niemcy wysuwają bez ustanku na forum międzynarodowe sprawę Pomorza tzw. u nich «korytarza polskiego», musimy im odpowiedzieć, że gdyby Prus nie było, nie byłoby także sprawy «korytarza»" 26 .

Do tematu Gdyni powróciła Helena Pankówna ze Szkoły Handlowej w Dąbrowie Górniczej, w artykule Gdynia i nasz handel morski27.

W numerze 27 z marca 1937 r. pojawił się wielostronicowy dodatek „Młodzież Morzu". Wstęp do niego napisał prezes Zarządu Obwodu Ligi Morskiej i Kolonialnej Zagłębia Dąbrowskiego w Sosnowcu K. Kucharski, a pismu towarzyszyło motto zaczerpnięte z przemówień prezydenta Ignacego Mościckiego „Miłość morza winna być źródłem, z którego czerpać będą swą moc przyszłe pokolenia Polski”28.

${ }^{23}$ L. M a rs z a łe k, Morze, „Młodzi Idą...” 1933, nr 2, s. 4.

${ }^{24}$ R y ś-M a r k, Nad Bałtykiem, tamże, nr 3, s. 13.

25 Zdzisław Kleindienst rok później zmarł, zob. Z żałobnej karty, „Młodzi Idą...” 1934, nr 10, s. 10.

${ }^{26}$ Z. K I e i n d i e n s t, U wrót Bałtyku pilną trzymamy straż..., „Młodzi Idą...” 1933, nr 4, s. 6-7.

27 H. P a n k ó w n a, Gdynia i nasz handel morski, „Młodzi Idą...” 1934, nr 11, s. 15.

${ }^{28}$ K. K u c h a r s k i, Nasze hasło, „Młodzież - Morzu. Dodatek Zjednoczonych Szkolnych Kół LMiK przy Czasopiśmie Młodzieży Szkolnej Młodzi Idą” 1937, s. 1, [wydanie specjalne do: „Młodzi Idą" 1937, nr 27]. 
Przekaz ideowy dodatku był niezwykle jasny, wystarczy zacytować tytuły: Frontem do kolonii29, Nasz ce/30, O potrzebie polskich kolonii, Nasi marynarze ${ }^{31}$, Polska chcąc być silną musi mieć kolonie ${ }^{32}$, Młodzież - morzu ${ }^{33}$, Rzeczywistość i sen ${ }^{34}$. Przy czym jeden z artykułów kończył się hasłem: ŻĄDAMY KOLONII DLA POLSKI!!!"35.

W 1938 r. do egzemplarzy „Młodzi Idą...” dodawano zeszyty „Jednodniówki Gdańskiej”, redagowane przez Zjednoczenie Kół Szkolnych Ligi Morskiej i Kolonialnej. Redakcja, zachęcając do ich czytania, pisała: „Nie wątpimy o tym, że wszyscy nasi czytelnicy są gorącymi przyjaciółmi morza, że kwestia Gdańska leży im wciąż na sercu"36. W styczniu 1939 r. opublikowano wiersz Tadeusza Robaka z Państwowego Liceum Pedagogicznego $\mathrm{Na}$ dziewiętnastolecie, wyraźnie zaznaczając, że utwór jest dedykowany polskiemu morzu ${ }^{37}$, a w marcu 1939 r. opublikowano artykuł ORP «Orzeł» przybywa do Gdyni38.

Innym z tematów, jaki starano się przybliżyć młodzieży, była gospodarka. Tematyka gospodarcza była szczególnie aktualna w czasach wielkiego kryzysu. Już w drugim numerze czasopisma „Młodzi Idą...” pojawił się tekst Heleny Dziubińskiej ze Szkoły Handlowej Kilka uwag o kryzysie ${ }^{39}$. W czwartym numerze ukazał się artykuł Co powinno nas interesować. Jego autorką była absolwentka Szkoły Handlowej w Dąbrowie Górniczej M. Milkówna, która, starając się przybliżyć problematykę kryzysu gospodarczego młodszym kolegom i koleżankom, pisała wtedy: „Żyjemy w czasach, w których każdy człowiek, troszczy się o jutro, obawia się, czy jutro rodzina jego nie będzie głodna, boi się czegoś, a tym czymś jest kryzys. Kryzys dał się we znaki wszystkim i we wszystkich dziedzinach: handlu, przemyśle i rolnictwie. Skąd się wziął kryzys? Mamy przecież dobrze rozwiniętą technikę, mamy surowce, które możemy eksportować. Niestety brak nam jest rynków zbytu, a dzisiejsza technika wydaliła z kopalń i fabryk tysiące pracujących; tam, gdzie przedtem pracowały rzesze, teraz pracuje kilku robotników, którzy obsługują maszyny. Wszystko mamy, wszystkiego jest nadprodukcja, tylko nie mamy pieniędzy. Słychać ciągle narzekania na dzisiejszą złą koniunkturę. Kryzys objął swymi zdradzieckimi szponami cały kraj. Nie tylko w Polsce załamała się koniunktura, ale prawie we wszystkich krajach"40.

W 1934 r. w czasopiśmie powstał „Dział Gospodarczy”, w którym pojawiły się takie artykuły, jak S. Wiewióry z PSGH Polski górnik we Francji o wysiedlaniu

${ }^{29}$ D. G a l ó w n a, Frontem do kolonii, „Młodzież - Morzu. Dodatek...”, s. 2.

30 L. K a s z y c k i, Nasz cel, tamże, s. 2.

31 Z. M i ś k i e w i c z, Nasi marynarze, tamże, s. 3.

${ }^{32}$ W. S i e r o s z e w s k i, Polska chcąc być silną musi mieć kolonie, tamże, s. 5.

33 Z. B u d z y ń s k i, Młodzież - morzu, tamże, s. 6.

${ }^{34}$ S. P r z y b yło w i c z ó w n a, Rzeczywistość $i$ sen, tamże, s. 6-8.

${ }^{35}$ K. Ko s i ń s k a, O potrzebie polskich kolonii, tamże, s. 4.

36 Informacja Redakcji, „Młodzi Idą” 1938, nr 34, s. 18.

37 T. R o b a k, Na dziewiętnastolecie, „Młodzi Idą” 1939, nr 39, s. 6.

${ }_{38}$ M. D y n e r, ORP „Orzeł” przybywa do Gdyni, tamże, nr 40, s. 3-4.

${ }^{39}$ H. D z i u b i ń s k a, Kilka uwag o kryzysie, „Młodzi Idą...” 1933, nr 2, s. 4.

40 M. M i I k ó w n a, Co powinno nas interesować, tamże, nr 4, s. 13. 
cudzoziemców (w dużej mierze polskich robotników) z Francji41, J. Szecówki Jak Polska walczy z kryzysem? ${ }^{42}$ czy też M. Wojtalównej ze Szkoły Handlowej Żeńskiej w Sosnowcu Znaczenie nauk.[owej] organizacji w handlu ${ }^{43}$.

Korespondując z tematyką gospodarczą, w pierwszym numerze w 1935 r. opublikowano artykuł popularyzujący wiedzę na temat działalności uniwersytetów robotniczych w Sosnowcu, Czeladzi i Dąbrowie Górniczej. Zygmunt Majchrzycki w tekście zatytułowanym Robotnik zagłębiowski - kładzie zręby pod Nową Polskę!... wychwalał ich działalność, podkreślając, że 500 słuchaczy w Sosnowcu, Czeladzi i Dąbrowie w ciągu pół roku zapozna się z około pięćdziesięcioma tematami poświęconymi historii, państwu, sprawom socjalnym ${ }^{44}$. Dalej umieszczono tekst, pełen nadziei na polepszenie sytuacji ekonomicznej, zatytułowany: Polsko-angielska umowa węglowa ${ }^{45}$. W lutym tego roku ponownie w „Dziale Gospodarczym” można było przeczytać tekst Heleny Pankównej z III klasy Szkoły Handlowej w Dąbrowie Górniczej pt. Polskie rybołówstwo morskie, w którym autorka przybliżała swoim kolegom i koleżankom kwestie ekonomiczne, związane z tą branżą. W zakończeniu zauważyła: „Sprawy, jak wyżej wymieniono, każda związana z morzem - są to sprawy milionów złotych - od umiejętnej organizacji, rzeczowego ich załatwienia i koordynacji wysiłków zależy dobrobyt i powodzenie"46.

Artykuły traktujące o gospodarce miały w dużej mierze charakter edukacyjny i wyjaśniały uczniom szkół zagłębiowskich zawiłości świata ekonomii. W październiku 1935 r. opublikowano tekst Krystyny Frątczakównej Uczmy się oszczędzać!, w którym autorka namawiała czytelników do systematycznego oszczędzania ${ }^{47}$. Czasopismo kończyło w ten sposób całą serię artykułów o gospodarce i ekonomii. Wraz z końcem kryzysu gospodarczego temat przestał być aktualny.

Nie unikano też problematyki politycznej. Informowano o wydarzeniach w Niemczech: „Według otrzymanych informacji bojówki hitlerowskie rozpoczęły akcję programową w Niemczech, skierowaną przeciwko obywatelom polskim. W szczególności akcja ta zwraca się przeciwko polskiej młodzieży. Nadchodzą szczegóły odnośne ohydnej napaści bandy szturmowców na grupę uczniów polskich we Wrocławiu - wracających wieczorem ze szkół do domów"48. W innym numerze czytamy: „Dzisiaj, gdy nad Europą zjawiają się chmury groźnej w swych następstwach zachłanności i buty niemieckiej, gdy Niemcy występują z Ligi Narodów, nie mogąc się zgodzić na pokojowe usposobienie świata, staje się szczególnie aktualną sprawa dostępu Polski do morza, a z nią zagadnienie Prus Wschodnich"49. W 1938 r. kilka artykułów poświęcono włączeniu Zaolzia ${ }^{50}$. Autorzy

41 S. W i e w i ó r a, Polski górnik we Francji, „Młodzi Idą...” 1934, nr 12, s. 17-18.

42 J. S z e c ó w k a, Jak Polska walczy z kryzysem?, tamże, s. 18-19.

${ }^{43}$ M. W o j t a l ó w n a, Znaczenie nauk. Organizacji w handlu. Wyjątki z referatu, tamże, s. 19-20.

44 Z. Majchrzy cki, Robotnik zagłębiowski - kładzie zręby pod Nową Polskę!..., „Młodzi Idą..." 1935, nr 13, s. 1-2.

${ }^{45} \mathrm{O}$ k u l a r n i k, Polsko-angielska umowa węglowa, tamże, s. 12.

${ }^{46}$ H. P a n k ó w n a, Polskie rybołówstwo morskie, tamże, nr 14, s. 14.

${ }^{47} \mathrm{~K}$. F r ą t c z a k ó w n a, Uczmy się oszczędzać!, tamże, nr 17, s. 8.

48 O., Przez pryzmat ostatnich wydarzeń, „Młodzi Idą...”, 3 V 1933, nr 2, s. 19.

${ }^{49}$ Z. K I e i n d i e n s t, U wrót Bałtyku pilną trzymamy straż..., „Młodzi Idą...”, 3 XI 1933, nr 3, s. 6.

50 M. R z e p k i e w i c z ó w n a, Po zwycięstwie, „Młodzi Idą” 1938, nr 37, s. 2-4; J. M o tł o c h, Nasza flaga za Olzą, tamże, s. 4-5; K. M a c h u r z a n k a, Wspomnienia zza Olzy, tamże, s. 5-6. 
pisma „Młodzi Idą...” włączali się w ten sposób do oficjalnego nurtu publicystyki politycznej tamtych czasów.

Redakcja na łamach swojego miesięcznika wspierała rozwój harcerstwa. Albin Piechota z IV klasy Seminarium pisał o harcerstwie m.in. : „W harcerstwie jest zatem stosowana tzw. metoda projektów, dość dzisiaj głośna i poruszana przez sfery pedagogiczne”, a także: „Harcerstwo, stawiając przed oczyma młodzieży ideała rycerza, jakim był Zawisza Czarny i zlecając spełnienie przynajmniej jednej przysługi dziennie, kieruje nagromadzone siły ku celom altruistycznym" 51. W 1935 r. opublikowano artykuł Ćwierćwiecze istnienia ruchu harcerskiego poza nami, w którym czytamy: „To zdobywanie umiejętności harcerskich (potrz. [ebnych] w życiu) w atmosferze swobody, to podniecanie naszej fantazji, wyrobienie ideowe, rozwój fizyczny - oto to, czego żadna organizacja nie może dać w takim stopniu, jak harcerstwo"52. B. Jędroszówna wyjaśniała symbolikę znaków harcerskich ${ }^{53}$. W czasopiśmie przedstawiano sprawozdania z działalności drużyn harcerskich, zjazdów ${ }^{54}$ i zlotów, szczególnie od 1937 r. W „Młodzi Idą...” pojawiła się m.in. relacja jednego z uczniów Gimnazjum im. W. Łukasińskiego w Dąbrowie Górniczej z międzynarodowego zlotu skautów w Vogelenzang w Holandii w 1937 r. ${ }^{55}$ Publikowano też wrażenia z obozów harcerskich w Polsce, jak np. Z. Ziembiński w artykule 44 Zagł.[ębiowska] Druż.[yna] Harc.[erska] nad Naroczą ${ }^{56}$. Rozpoczęto redagować „Dział Harcerski”, w którym opublikowano relację z przekazania sztandaru harcerskiego z 1914 r. drużynie harcerskiej przy Państwowym Gimnazjum im. E. Plater ${ }^{57}$. W 1938 r. ukazał się też reportaż Na progu leśnego życia, będący relacją z obozu harcerskiego ${ }^{58}$.

Promowano sport. Pojawiały się artykuły popularyzujące hokej ${ }^{59}$, narciarstwo ${ }^{60}$, szybownictwo ${ }^{61}$, siatkówkę i koszykówkę ${ }^{62}$, a także piłkę nożną. W piątym numerze czasopisma opublikowano relację z meczu piłki nożnej Polska - Niemcy63. W jednym z tekstów dotyczących hokeja czytamy: „Trzecia i ostatnia tercja. Zaraz

${ }^{51}$ A. P i e c h o t a, O wartości wychowawczej harcerstwa, „Młodzi Idą...”, 3 V 1933, nr 2, s. 6.

$52 \mathrm{Jur}$ Włóczykij D w u dziestka, Ćwierćwiecze istnienia ruchu harcerskiego poza nami, „Młodzi Idą...” 1935, nr 17, s. 2.

53 B. J ę d ro s z ó w n a, Nasz krzyż, „Młodzi Idą” 1937, nr 28, s. 3.

${ }^{54}$ We s oły Koń z D wójk i, Co robią harcerze w zimie?, „Młodzi Idą...” 1936, nr 25, s. 14; Z. S z m a I, Zjazd instruktorów i drużynowych Chorągwi Zagł., „Młodzi Idą” 1937, nr 27, s. 7; W. S a w c z e n k o, Sprawozdanie z działalności 82-ej Drużyny Harcerskiej im. K. Pułaskiego w Sosnowcu, tamże, nr 29, s. 13-14.

55 J. S k r z y w a n e k, Jamboree... Jamboree..., „Młodzi Idą” 1937, nr 30, s. 5-6.

56 Z. Z i e m b i ń s k i, 44 Zagł. Druż. Harc. nad Naroczą, tamże, s. 13-14.

57 I. B u r a k ó w n a, Witaj sztandarze Słonecznej Drużyny, „Młodzi Idą” 1937, nr 31, s. 9-10.

58 I. B u r a k ó w n a, Na progu leśnego życia, „Młodzi Idą” 1938, nr 36, s. 12-13.

59 J. W i t k o w s k i, Sport, „Młodzi Idą...” 1933, nr 5, s. 14; H. K u l a w i k, Słowa z pod krążka, „Młodzi Idą...” 1934, nr 6-7, s. 9; H. Ko ś m i d e r, Hockej! Hockej!, tamże, s. 18.

60 Z. Z i e m b i ń s k i, Białe szaleństwo, „Młodzi Idą” 1937, nr 27, s. 8; K r-F r, Biała przygoda, „Młodzi Idą...” 1939, nr 39, s. 14-16.

61 M. S i ł u s z e k, Szybownictwo, „Młodzi Idą...” 1934, nr 6-7, s. 17; W. L., Szybownictwo, „Młodzi Idą..." 1935, nr 18-19, s. 15-16; W. L., Polska a znaczenie szybownictwa, „Młodzi Idą...” 1936, nr 20, s. 15-16; W. L., Fragmenty z szybowiska, tamże, nr 21, s. 13-14.

62 K. S z l e z y n g i e r, Mistrzostwa Szkół średnich Zagłębia, „Młodzi Idą” 1937, nr 31, s. 19.

63 M. P a j k e r tó w n a, Polska - Niemcy, „Młodzi Idą...” 1933, nr 5, s. 14. 
na początku pada strzał Sokołowskiego, triumfatora dnia dzisiejszego. Strzał tak śliczny, że początkowo nie można znaleźć krążka. Znowu gra. Gorący moment pod naszą bramką. Strzał. Niezrównany "Stoga» obronił. W dalszej grze padają jeszcze dwie bramki z rąk, a właściwie z kija Króla i Marchewczyka. Brawo!!! Koniec gry. Polska wygrała z mistrzem Europy w stosunku 5:0. Żal mi było tylko jednej osoby, Wołkowskiego. Tak chciał gola strzelić, a tu nic. Trudno, pech. Ja też miałem na drugi dzień pecha i to gorszego. Profesor wygrał ze mną w stosunku 2:0"64.

Na uwagę zasługują liczne publikowane w czasopiśmie reportaże. Wszystkie pisane przez uczniów szkół Dąbrowy Górniczej, Będzina czy Sosnowca, były często ich debiutami literackimi. Szczególną okazję do tego typu publikacji dawały numery ukazujące się po wakacjach czy feriach zimowych. Pojawiały się reportaże z wycieczek szkolnych, np. w 1933 r. zamieszczono artykuł Dąbrowa Górn.[icza] - Warszawa - Wilno, w którym znajdują się opisy podróży koleją, zwiedzanych miejsc, a także osobiste refleksje autora, związane z poszczególnymi zabytkami65. W tym samym roku można było przeczytać Reportaż z «Zakładu fryzjerskiego dla pańı" autorstwa Zofii Wąsowiczównej z Gimnazjum im. E. Plater w Sosnowcu66. W następnych latach publikowano m.in.: W. Rybaka KielceSandomierz ${ }^{67}$ i Polskie Baku. Wrażenia z wycieczki po Małopolsce Wschodniej68, a także Barbary Jędroszównej z Gimnazjum im. Zawidzkiej w Dąbrowie Górniczej Wrażenia z wycieczki do Warszawy ${ }^{69}$.

Ukazywały się opowiadania i nowele, jak np. B. Witki „Do synów”70 czy Korepetytor ${ }^{71}$ podpisany: „Dzidek” z KI. [Kolega] „Kantem”, ilustrowany przez B. Siejeńskiego i dedykowany Wieśkowi H. W 1936 r. ukazywały się takie utwory jak: Młodość Zygmunta Majchrzyckiego ${ }^{72}$, Okulary 0,75D Witolda Majchrowskiego ${ }^{73}$, Tak było Tadeusza Korczewskiego ${ }^{74}$, Ludzie zza płotu Zbigniewa Budzyńskiego ${ }^{75}$, Bursztyn Z. Porgulskiego ${ }^{76}$. W 1937 r. teksty publikowali uczniowie: Barbara Jędroszówna ${ }^{77}$, Bogda Krzenikówna ${ }^{78}$, K. Goeblówna ${ }^{79}$, Roman Retman ${ }^{80}$, M. Fuchs ${ }^{81}$, B. Ramotowska ${ }^{82}$, Krystyna Dynerówna ${ }^{83}$.

64 J. S. Polska-Niemcy, „Młodzi Idą...” 1934, nr 8, s. 12-13.

${ }^{65}$ U c z e s t n i k, Dąbrowa-Górn. - Warszawa - Wilno, „Młodzi Idą...” 1933, nr 4, s. 10-12.

${ }^{66}$ Z. W ą s o w i c z ó w n a, Reportaż z „Zakładu fryzjerskiego dla pań”, tamże, nr 5, s. 16.

${ }^{67}$ W. R y b a k, Kielce-Sandomierz, „Młodzi Idą...” 1934, nr 10, s. 6-9.

${ }^{68}$ Te n ż e, Polskie Baku. Wrażenia z wycieczki po Małopolsce Wschodniej, tamże, s. 8-9.

${ }^{69}$ B. J ę d r o s z ó w n a, Wrażenia z wycieczki do Warszawy, „Młodzi Idą...” 1936, nr 24, s. 6.

${ }^{70}$ B. W i t k a, Do synów, „Młodzi Idą...” 1934, nr 11, s. 10-14.

71 „Dzidek” z KI. „Kantem”, Korepetytor, „Młodzi Idą...” 1934, nr 12, s. 5-6; część druga [w:] „Młodzi Idą..." 1935, nr 13, s. 4-5.

${ }^{72}$ Z. M a j c h r z y c k i, Młodość, „Młodzi Idą...” 1936, nr 21, s. 9-11.

${ }^{73}$ W. M a j c h r ow s k i, Okulary 0,75D, tamże, nr 23, s. 4.

${ }^{74}$ T. Ko r c z e w s k i, Tak było, tamże, nr 24, s. 3-6.

${ }^{75}$ Z. B u d z y ń s k i, Ludzie z za płotu, tamże, nr 25, s. 8-10.

${ }^{76}$ Z. P orguls k i, Bursztyn, tamże, s. 12.

77 B. Ję d r o s z ó w n a, Pieśń huculska, „Młodzi Idą” 1937, nr 27, s. 5.

${ }^{78}$ B. Krzenikó wn a, Marzec, tamże, s. 4.

${ }^{79}$ K. G o e b ló w n a, Mój pierwszy smutek, tamże, nr 28, s. 2.

${ }^{80}$ R. R e t m a n, Podzwonne mistrzowi..., tamże, s. 4.

${ }^{81}$ M. F u c h s, Za chlebem, tamże, s. 4.

${ }^{82}$ B. R a m o t o w s k a, Wróg, tamże, s. 6.

${ }^{83}$ K. D y n e ró w n a, Młodzież w 2037 r., tamże, s. 10-11. 
Pojawiały się przykłady uczniowskich prób poetyckich. Drukowano wiersze wygłaszane podczas wieczorów literackich w szkołach ${ }^{84}$. Dawało to możliwość prawdziwych debiutów literackich uczniów i uczennic. Swoje wiersze publikowali m.in. L. Marszałek z Państwowej Szkoły Górniczo-Hutniczej ${ }^{35}$, Witold Pękalski i Modest Kałużny z Seminarium Nauczycielskiego w Dąbrowie Górniczeje6, Maria Biskupówna z Gimnazjum J. Krzymowskiej i W. Replińskiej w Będzinie, C. Budkiewiczówna z Gimnazjum E. Plater ${ }^{87}$, Stefan Łubieński z Gimnazjum im. W. Łukasińskiego w Dąbrowie Górniczeje ${ }^{88}, \mathrm{H}$. Borowiec z Gimnazjum Zgromadzenia Kupców w Będzinie ${ }^{89}$, a także Mirosław Czarnomorski, J. Gosiewski, Bogusław Siejeński, Józef Sajdak ${ }^{90}$. Były to pierwsze poetyckie próby. Przykładem może być wiersz W nadziei świtu Zofii Koczorowskiej z klasy VI Gimnazjum Żeńskiego w Dąbrowie Górniczej:

\author{
W nadziei świtu \\ Uderzać w młoty, \\ I kuć z granitu \\ Własne tęsknoty \\ O słońcu marzyć \\ W nędznym światełku, \\ Z smutkiem na twarzy \\ Wśród pracy zgiełku. \\ Na czyjeś przyjście \\ Czekać w szybiku, \\ Może się ziści \\ Sen o skarbniku? ${ }^{91 "}$
}

Od 1934 r. regularnie redagowano „Kolumnę Poetycką”. Pismo przyczyniło się do powstania Klubu Artystyczno-Literackiego „KANTEM” w Sosnowcu. Wiosną 1934 r. w Teatrze Miejskim w Sosnowcu „KANTEM” zorganizował Wieczór Poezji Współczesnej. Celem klubu była wymiana poglądów, wzajemna krytyka własnych utworów, a przede wszystkim poznanie literatury współczesnej i jej prądów nieuwzględnianych w programach szkolnych ${ }^{92}$.

W lutym 1935 r. w „Kolumnie Poetyckiej”, ale także na innych stronach czasopisma, swoje wiersze publikowali: H. Sojka, Aleksander Antyporowicz

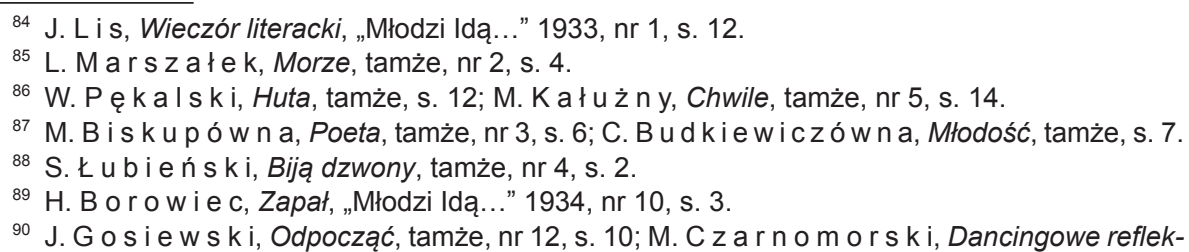
sje, tamże, s. 10; B. S i e j e ń s k i, Fiord, tamże, s. 11; J. S a j d a k, Lot w fantazję, tamże, s. 10-11.

91 Z. K o c z o r o w s k a, W nadziei świtu, „Młodzi Idą...” 1933, nr 4, s. 12.

92 Do klubu należeli: A. Antyporowicz, A. Bukko, E. Ciopa, Z. Dobrowolski, L. Kotnowski, W. Krajewski, W. Lempert, W. Majchrowski, H. Sojka, W. Stacherski, L. Stecki. Zob. Klub Art.-Lit. „KANTEM” w Sosnowcu, „Młodzi Idą...” 1934, nr 12, s. 12. 
i A. Jasieńczuk ${ }^{93}$; w 1936 r. Danuta Kucharska94, rok później: W. Stacherski, B. Konecki, Z. Budzyński ${ }^{95}$, Jerzy Skrzywanek, Maria Sikorska, H. Dąbrowski ${ }^{96}$, J. Piotrowski ${ }^{97}$, Jerzy Gruba ${ }^{98}$, Leonard Żyłka ${ }^{99}$; w 1938 r.: Leszek Wysznacki' ${ }^{100}$, Tadeusz Śpiewakowski ${ }^{101}$, Irena Burakówna ${ }^{102}$ i Wiesława Jaxa-Bykowska ${ }^{103}$.

Osobną grupę artykułów stanowiły recenzje filmów i przedstawień teatralnych. W pierwszym numerze czasopisma pojawiła się krytyka Warszawianki i fragmentu Wesela Stanisława Wyspiańskiego wystawianego przez uczniów PSGH. W dość ostrych słowach napisano: „Jakie fatum wisiało nad sceną, że w chwili najwyższego napięcia - brak napięcia, w chwili wymarszu wojska - brak zapału (i wojska; jedynie trębacz, a może to Wiarus trąbi?), że w chwili gromkich słów Chłopickiego - śmiech na sali"104. W następnym numerze pisma ukazała się odpowiedź L. Orłowskiego z PSGH, który bronił uczniów ${ }^{105}$.

Podejmowano się też recenzji filmowej. Przykładem może być krytyczny artykuł dotyczący polskich filmów komediowych Thalia a filmy polskie, w którym autor Tadeo Zet - narzeka na dość słabą jakość polskich komedii i wyraża nadzieję na podniesienie ich poziomu w wyniku współpracy polsko-czeskiej ${ }^{106}$.

W 1934 r. opublikowano artykuł Z. Dobrowolskiego i W. Majchrowskiego Szekspir "stonowany», w którym pojawiła się recenzja inscenizacji Snu nocy letniej na deskach Teatru Miejskiego w Sosnowcu. Czytelnicy mogli zapoznać się z kulisami powstania tej inscenizacji, a tekst ogólnie zachęcał do pójścia do teatru, aby na własne oczy obejrzeć to udane przedsięwzięcie artystyczne ${ }^{107}$.

W styczniu 1935 r. ukazały się dwie recenzje filmów polskich. W tekście dotyczącym filmu Przeor Kordecki - Obrońca Częstochowy nie szczędzono słów krytyki: „Technika zdjęć i tonu także wiele pozostawia do życzenia. Muzyka ilustrująca film z XVII w. (...saksofony), zagłuszała dialogi tak, że jedynie dzięki szerokiemu otwieraniu ust, można było zrozumieć bohaterkę filmu, czego o innych osobach trudno powiedzieć, co było jej osobistą zasługą. Trudno było zróżniczkować pieśni polskiej husarii i szwedzkiej rajtarii, wskutek podobieństwa. O grze innych artystów można powiedzieć, że np. bracia Małynicze (nazwisk

93 H. S o j k a, Chciałem z Tobą porozmawiać, „Młodzi Idą...” 1935, nr 14, s. 8; A. A n t y p o r o w i c z, Marzenie, tamże, s. 8.; A. J a s i e ń c z u k, Lot w stratosferę, tamże, s. 8.

94 D. K u c h a r s k a, Kroki, „Młodzi Idą...” 1936, nr 24, s. 6.

95 Z. B u dz y ń s k i, Środa Popielcowa, tamże, nr 26, s. 6; B. K o n e c k i, Tęsknota, tamże, s. 6; W. S t a c h e r s k i, Ad amicum, tamże, s. 6.

${ }^{96}$ H. D ą b r o w s k i, Lata moje młode!, „Młodzi Idą” 1937, nr 27, s. 9; M. S i k o r s k a, Dzwony, tamże, s. 9; J. S k r z y w a n e k, Urosłaś mi..., tamże, s. 9.

97 J. P i o tr o w s k i, Wiosna, tamże, nr 28, s. 2.

98 J. G ru b a, Lato leniwe, tamże, nr 31, s. 6.

99 L. Ż yłk a, Żołnierskie groby, tamże, s. 2.

100 L. W y s z n a c k i, Wieczorem, „Młodzi Idą” 1938, nr 33, s. 9.

101 T. Ś p i e w a k o w s k i, Śnieg, tamże.

102 I. B u r a k ó w n a, Śnieżne płatki za oknem, tamże, s. 10.

103 W. J a x a-B y k o w s k a, Białe bzy..., tamże, nr 35, s. 8.

104 W. M o l e n d z k i, Płaszcz i Napoleon, „Młodzi Idą...” 1933, nr 1, s. 14.

105 L. O rło w s k i, „Płaszcz i Napoleon” w oświetleniu, tamże, nr 2, s. 18-19.

106 Tamże, s. 16.

107 Z. D o b r o w o I s k i, W. M a j c h row s k i, Szekspir „stonowany”, „Młodzi Idą...” 1934, nr 12, s. $13-14$. 
odtwórców niestety nie pamiętam) byli „par excellence” nowocześni, wywracali białkami, jak murzyn dżezzbandzista; poza tym poza i patos, patos i poza"108. Natomiast recenzja filmu Młody Las w reżyserii J. Lejtesa była już bardzo pozytywna: „Kreacje Jaracza, Cybulskiego, K. Pawłowskiego, Turkowa czy Bogdy lub choćby misternie cyzelowane epizody Znicza, Waltera, Stępowskiego i wielu innych, winny się stać niewątpliwie punktem zwrotnym w ich karierach - a może i całej filmji [kinematografii] polskiej"109.

Tematem recenzji były często aktorskie przedsięwzięcia uczniów z zaprzyjaźnionych szkół, jak na przykład inscenizacja Wyzwolenia J. Słowackiego, przygotowana przez zespół PSGH, ale także profesjonalnie grana Nie-Boska komedia Z. Krasińskiego wystawiana w Teatrze Miejskim w Sosnowcu ${ }^{110}$. W listopadzie 1935 r. ukazała się bardzo przychylna recenzja sztuki G. B. Shawa Nigdy nic nie wiadomo, wystawianej w reżyserii J. Gołaszewskiego, dyrektora Teatru Miejskiego w Sosnowcu ${ }^{111}$. W maju 1936 r. zrecenzowano Skąpca Moliera w inscenizacji Koła Dramatycznego przy Gimnazjum im. S. Staszica, przy współudziale uczennic z Gimnazjum im. E. Plater. Tekst mógł tylko zachęcać do dalszej pracy. W recenzji czytamy: „Reżyserom należy podziękować za troskliwe wypracowanie scen i sytuacji, które mimo, że sztuka była grana przez amatorów, w żadnym momencie nie sprawiły wrażenia ujemnego"112. Podobnie przychylnie przyjęto Śluby panieńskie A. Fredry, wystawiane w 1937 r. przez Koło Sceniczne Gimnazjum im. S. Staszica ${ }^{113}$.

W marcu tego r. pojawiła się recenzja z wystawy artystów plastyków w sosnowieckim ratuszu ${ }^{114}$.

Od roku 1935 pojawiały się recenzje książek. Już w styczniu prezentowano książki: Franklina D. Roosevelta Spojrzenie w przyszłość, J. M. Rytarda i H. Roj-Rytardowej Koleba na Hlinku115, a później Jerzego Smoleńskiego Morze i Pomorze, czy Zbrodni Cyryla Bezsonowa ${ }^{116}$, Emila Zegadłowicza Zmory ${ }^{117}$, Jarosława Iwaszkiewicza Czerwone Tarcze, Marii Kuncewiczowej Dyliżans warszawski118. Z okazji wydania zbiorowego dzieł Bolesława Prusa w czasopiśmie pojawił się artykuł Rocha Turonia Renesans Prusa, w którym autor zaznaczył, że rosnąca popularność Prusa odbywa się kosztem Sienkiewicza. Argumentował: „Pokolenie dnia dzisiejszego, pokolenie twardej rzeczywistości,

${ }^{108}$ Okularnik, Przeor Kordecki - Obrońca Częstochowy, „Młodzi Idą...” 1935, nr 13, wewnętrzna strona okładki.

109 W. L e m p e r t, „Młody Las”, tamże.

110 Z. D o b r o w o I s k i, Nie-Boska Komedia Zygmunta Krasińskiego. Teatr Miejski w Sosnowcu, tamże, nr 17, s. 10.

111 W. Majchrowski, W. Lempert, Nigdy nic nie wiadomo. Komedia w 4 aktach G. B. Shaw’a. Inscenizacja i reżyseria dyr. J. Gołaszewskiego, „Młodzi Idą...” 1935, nr 18-19, s. 11.

112 W. S t a c h e r s k i, Scena uczniowska: Skąpiec, „Młodzi Idą...” 1936, nr 22, s. 12.

113 Z. B u d z y ń s k i, Magnetyzm serca, „Młodzi Idą” 1937, nr 27, s. 6.

114 J. Sajdak, Z. Gibałk o, Z wystawy art.-plastyków w ratuszu, „Młodzi Idą...” 1935, nr 15, s. 13.

115 W. L e m p e r t, Co czytać?, tamże, nr 13, s. 10.

116 W il k oła z, Co czytać?, tamże, nr 14, s. 10; J. S a jdak, Co czytać?, tamże, s. 10.

117 J. N a jm a n, Co czytać?, tamże, nr 17, s. 11.

118 A. Telat y cki, H. Pi a s kow ska, Co czytać?, tamże, nr 15, s. 11. 
pokolenie zrównane wreszcie, w swych zainteresowaniach, wybrało realistę Prusa, pisarza na wskroś społecznego"119. W 1937 r. polecano książkę Marii Dąbrowskiej Rozdroże ${ }^{120}$ i Melchiora Wańkowicza Na tropach Smętka121.

W lutym 1935 r. zamieszczono „Przegląd wydawnictw periodycznych”, w którym zachęcano młodzież Zagłębia do czytania takich pism, jak: „Tygodnik llustrowany”, „Pion”, „Nowe Czasy”, „Prosto z mostu”, „Gazeta Artystów”, „Dekada” i „Kuźnia Młodych”122. W kolejnym numerze Wojciech Proch zachęcał do zapoznania się z treścią „Podchorążego” - prasowego organu szkół podchorążych, a także do czytania „Literatury w Szkole” i „Tęczy”"123.

Na łamach „Młodzi Idą...” popularyzowano też sylwetki pisarzy. W styczniu 1936 r. przedstawiono życiorys i dorobek pisarski Zofii Nałkowskiej i Rudyarda Kiplinga ${ }^{124}$. W tym samym numerze zachęcano do lektury książki Józefa Wittlina Sól ziemi ${ }^{125}$.

Ważnym elementem, który pojawiał się na łamach „Młodzi Idą...” to wywiady. W czwartym numerze, w listopadzie 1933 r., pojawił się tekst Witolda Molendzkiego z Gimnazjum im. Łukasińskiego, zatytułowany Wyrąbanym chodnikiem do Gustawa Morcinka. Redaktor przeprowadził z pisarzem rozmowę na temat sztuki na Śląsku i w Zagłębiu ${ }^{126}$. Miesiąc później w „Młodzi Idą...” opublikowano tekst odczytu, jaki Gustaw Morcinek wygłosił w dniu św. Barbary w Akademii Górniczo-Hutniczej w Dąbrowie Górniczej ${ }^{127}$. W innym numerze z maja 1934 r. zamieszczono wywiad z Zofią Kossak-Szczucką ${ }^{128}$. W marcu 1935 r. opublikowano wywiad z Emilem Zegadłowiczem ${ }^{129}$, w październiku tego roku z Julianem Tuwimem ${ }^{130}$, a w styczniu 1936 r. wywiad z Leonem Kruczkowskim ${ }^{131}$. W lutym 1937 r. jednemu z redaktorów „Młodzi Idą...” krótkiego wywiadu udzielił, przebywający w uzdrowisku w Jaworzu na Śląsku Cieszyńskim, Ferdynand Goetel ${ }^{132}$. W 1938 r. opublikowano też wywiad z Tadeuszem Kudlińskim ${ }^{133}$.

119 R. T u r o ń, Renesans Prusa, „Młodzi Idą...” 1935, nr 17, s. 15.

120 R. R e t m a n, Co czytać?, „Młodzi Idą 1937, nr 30, s. 15.

121 W. M e d y ń s k i, Co czytać?, „Młodzi Idą” 1937, nr 31, s. 17-18.

122 Z. M a j c h r z y c k i, Przegląd wydawnictw periodycznych, „Młodzi Idą...” 1935, nr 14, s. 17.

123 W. P r o c h, Przegląd wydawnictw periodycznych, „Młodzi Idą...” 1935, nr 15, s. 17.

124 S. Z a I c, Zofia Nałkowska, „Młodzi Idą...” 1936, nr 20, s. 9; A. T e l a t y c k i, Rudyard Kipling, tamże, s. 9.

${ }^{125}$ A. Te l a t y c k i, Co czytać?, tamże, s. 14.

126 W. Mole n dzk i, Wyrąbanym chodnikiem do Gustawa Morcinka, „Młodzi Idą...” 1933, nr 4, s. 4-6.

127 G. M o r c i n e k, Górnik i hutnik w literaturze. Odczyt wygłoszony w dniu św. Barbary w Akademii Górniczo-Hutniczej w Dąbrowie Górniczej, tamże, nr 5, s. 18.

${ }_{128}$ Redakcji „Młodzi Idą” Zofia Kossak-Szczucka [wywiad], „Młodzi Idą...” 1934, nr 9, s. 2-5.

${ }^{129}$ W. Le mpert, W. Majch row ski, Wywiad z Emilem Zegadłowiczem, "Młodzi Idą..." 1935, nr 15, s. 4-5.

${ }^{130}$ W. M a j c h r o w s k i, W. L e m p e r t, Kilka chwil z Julianem Tuwimem, tamże, nr 17, s. 3.

131 W. Majchrowski, Rozmowa z autorem „Kordiana i Chama”, „Młodzi Idą...” 1936, nr 20, s. 2-3.

132 Z. W i t c z y ń s k i, Spotkanie z Goetlem, tamże, nr 26, s. 4.

133 J. S k r z y w a n e k, Wywiad z Tadeuszem Kudlińskim, „Młodzi Idą” 1938, nr 35, s. 17-19. 
Od początku istnienia czasopisma pojawiały się propozycje konkursów literackich. Pierwsze propozycje tematów to: Konieczność wydawania pisma Młodzi Idą, Zagadnienie współpracy i współżycia szkół naszego miasta, Nowela (temat dowolny). Autorów najlepszych prac nagradzano książkami. Równolegle organizowano konkursy na najlepszą okładkę ${ }^{134}$. W grudniu 1933 r. ogłoszono konkurs fotograficzny: Młodzi idą? Zagłębie... Szkoła... Sport... W konkursach literackich przyznawano nagrody w kategoriach: wiersz, artykuł, nowela, reportaż. W 1937 r. zorganizowano konkurs deklamatorski. W ogłoszeniu czytamy: „Deklamatorzy! Redakcja „Młodzi Idą...” urządza wielki konkurs deklamatorski o tytuł mistrza i mistrzyni Zagł.[ębia] Dąbr.[owskiego] z nagrodami. Teksty dokładne z podaniem autora należy składać do dnia 8 III 37 r."135 W tym samym roku, chcąc zachęcić młodzież do żywszej współpracy przy redagowaniu grudniowego numeru „Młodzi Idą”, ogłoszono konkurs literacki i rysunkowy, poświęcony Zagłębiu ${ }^{136}$. Nagrodzone prace zostały opublikowane w 32 (grudniowym) numerze miesięcznika ${ }^{137}$. Ponieważ tematyka dotyczyła regionu, w dziale dla najmłodszych pojawił się artykuł Mariana Bugaja Historia Dąbrowy Górniczej ${ }^{138}$. Konkurs literacki ogłoszono także w kwietniu 1938 r. Temat był dowolny. Przewidziano nagrody książkowe za najlepszą nowelę i „za najlepszy artykuł o treści poważnej"139.W końcu tego roku ogłoszono konkurs na najlepszy artykuł na temat Moja klasa, a w komisji konkursowej mieli zasiąść nauczyciele poloniści z zainteresowanych szkół140. W 1939 r. odbył się kolejny konkurs deklamatorski. W relacji z konkursu można przeczytać, że: „sam dobór poezji, jak i wykonanie stały na wysokim poziomie artystycznym, co zresztą miało swój wyraz w hucznych, czasem spontanicznych oklaskach"141. Zwyciężczynią została uczennica Gimnazjum im. Rzadkiewiczowej B. Nawrocka, która deklamowała fragment wiersza Jana Kasprowicza Wielki Boże, wielki mocny.

W pierwszych numerach, w dziale „Rozrywki umysłowe” proponowano m.in. szarady, logogryfy, arytmografy i zadania matematyczne ${ }^{142}$. Jednak później zrezygnowano z redagowania tej kolumny.

Przez cały czas funkcjonowania czasopisma prowadzono na jego łamach działalność informacyjną. W dziale zatytułowanym początkowo „Kronika” umieszczano sprawozdania i informacje na temat działalności m.in. samorządów szkolnych, kół LOPP, kół PCK, drużyn harcerskich w poszczególnych szkołach ${ }^{143}$.

134 Ogłoszenie, „Młodzi Idą...” 1933, nr 1, s. 22.

135 Ogłoszenie, „Młodzi Idą...” 1936, nr 26, s. 6.

136 Konkurs, „Młodzi Idą” 1937, nr 31, s. 19.

137 L. Ż y łk a, Moje szare Zagłębie, „Młodzi Idą” 1937, nr 32, s. 3-4; M. M a m e l o k ó w n a, Cześć Pracy!, tamże, s. 4-5; J. L i p i ń s k i, Ofiara..., tamże, s. 5-7; M. O s tr o w s k i, Zagłębie w nocy, tamże, s. 7.

${ }_{138}$ M. B u g a j, Historia Dąbrowy Górniczej, tamże, s. 15-16.

139 Konkurs, „Młodzi Idą” 1938, nr 35, s. 15.

140 Wielki konkurs, tamże, nr 38, s. 17.

141 J. S., Poranek deklamatorski, „Młodzi Idą” 1939, nr 39, s. 17.

142 Rozrywki umysłowe, "Młodzi Idą...” 1933, nr 1, s. 20; Rozrywki umysłowe, tamże, nr 2, s. 21.

143 Kronika, tamże, nr 1, s. 16-18; Kronika Gimn. Zgr. Kupców w Będzinie, tamże, nr 2, s. 17; 
Zachęcano do współpracy z kołem fotograficznym z Gimnazjum Łuk ${ }^{144}$, informowano o istnieniu takiego $w$ przy gimnazjum w Będzinie ${ }^{145}$. W trzecim numerze czytamy: „Gimnazjum Będzińskie Zgrom. Kupców zaprasza: na Pierwszą Wystawę Fotografiki na terenie szkoły. Otwarcie wystawy nastąpi w sobotę 30 września o godz. 16-tej w Sali rysunkowej. Wystawa otwarta codziennie od godz. 16-ej do 18-ej, wstęp dla młodzieży 5 gr., dla starszych $10 \mathrm{gr}$. Wiele spośród wystawionych prac jest na poziomie naprawdę artystycznym. Koło Miłośników Fotografii.

Na sprawozdawczy referat kol. Jerzego Smoczarskiego z udziału w słynnym spływie kajaków Wisłą do polskiego morza w czasie wakacji b.r. Referat zostanie wygłoszony $w$ jednej z klas również w sobotę 30 września o godzinie 17.30. Przewidywane ilustrowanie referatu zdjęciami przez latarnię projekcyjną. Koło Przyjaciół Dobrej Książki ${ }^{146 "}$.

Później systematycznie kontynuowano pomysł redagowania sprawozdań, np. w końcu 1936 r., kiedy przedstawiono wydarzenia z Gimnazjum im. H. Rzadkiewiczowej, Gimnazjum im. S. Wyspiańskiego i Gimnazjum im. Staszica ${ }^{147}$. W 1937 r. w „Dziale informacyjno-sprawozdawczym” szczegółowo informowano o działalności samorządu uczniowskiego i szkolnych organizacji m.in. w Gimnazjum im. H. Rzadkiewiczowej ${ }^{148}$, Gimnazjum Państwowym im. E. Plater ${ }^{149}$, Państwowej Szkole Zawodowej Żeńskiej w Sosnowcu ${ }^{150}$, Szkole Handlowej Żeńskiej im. Królowej Jadwigit51.

Młodym autorom, których utwory nie trafiły na łamy pisma udzielano rad: „Kol. Kazio B-ski, Sem.: Mgła nieco sztuczna: wicher, promień słoneczny i... mgła, - to coś za dużo na mały wierszyk. Kol. Włodzimierz M-ik, Sem.: Nowelka niezła, ale czy temat ma coś wspólnego z młodymi, co idą? Ojczyzna nasza już dawno przecież wyrosła z krwi tych bohaterów"152. Kol. G. B-ska: Temat poważny, ale ujęcie płytkie i znać pewne niedociągnięcia stylowe, które w dalszych artykułach prawdopodobnie znikną. Kol. „Danka”, gimn. Plater: Wynurzenia Koleżanki mają zbyt osobisty charakter, aby w ogóle nadawały się do naszego pisma. Prosimy o intensywniejszą współpracę. Kol. O. B-ska, Sosnowiec: Praca o niezaprzeczalnych walorach literackich, ale są duże błędy w części pierwszej. Kol. Zdzisław R-ski, Śląsk. Techn. Zakł. Nauk.: Styl barwny i znać pracę, ale elaborat nic nowego nie przynosi. Prosimy Was i Kolegów o współpracę. Kol. „Jerry”, szkoła Handl.: W artykulikach wiele pięknych myśli, ale przysypane są popiołem banalności. Kol. J. 01, Sem.: Forma cokolwiek szwankuje, a sam motyw

Z działalności Kółka PCK przy Gimnazjum Żeńskim Krzymowskiej i Replińskiej w Będzinie, tamże, s. 18.

144 J. Hor w a t t-B o ż y c z k o, Fotografia, tamże, nr 2, s. 13.

145 Kronika Gimn. Zgr. Kupców w Będzinie, tamże, s. 18.

${ }^{146}$ Hallo! Tu Gimnazjum Zgromadzenia Kupców w Będzinie, „Młodzi Idą...” 1933, nr 3, s. 17.

147 Kronika szkolna, „Młodzi Idą...” 1936, nr 25, s. 17.

148 B. B r a u n e ró w n a, Gimnazjum im. H. Rzadkiewiczowej, „Młodzi Idą” 1937, nr 29, s. 11.

149 K. K o s i ń s k a, Gimnazjum Państw. imienia E. Plater, tamże, s. 12-13.

150 A. $Ł$ a b ę d z i a n k a, Państw. Szkoła Zawodowa Żeńska w Sosnowcu, tamże, s. 13.

151 Szkoła Handl. Żeńska im. Królowej Jadwigi, tamże, s. 13.

152 Redakcja mówi..., „Młodzi Idą...” 1933, nr 2, s. 20. 
mało oryginalny, ale łatwość wierszowania duża. Prosimy o współpracę"153. Czasem nie żałowano słów krytyki: „Kol. L. B. Artykulik mało oryginalny. Porównania tchną sztucznością. Najwyżej nadawałby się do „Płomyczka” [...] Kol. Ka-Ka. Rymoróbstwo. I to jeszcze podlejszego gatunku... wieje - epopeje... nieszczęścia - do szczęścia...to śpiewa łagodnie - tam znów... chłodnie (widoczny wpływ Pana Tadeusza, ale darujcie Mickiewiczowi nie dorównaliście). Piszcie kolego lepiej prozą. Kol. M. Z-ch. Wypracowanie. Same banalności. O tym wie już dziecko w ochronce. Oczekujemy jakiegoś obrazka z życia szkolnego"154. Można stwierdzić, że miesięcznik „Młodzi Idą...” posiadał liczne wartości edukacyjne. Był świetną szkołą dla tych wszystkich uczniów szkół Zagłębia Dąbrowskiego, którzy chcieli spróbować swoich sił w pracy redakcyjnej. Także tematyka i dobór treści czyniły to pismo niezwykle wartościowym zarówno pod względem merytorycznym, jak i wychowawczym. Uczono patriotyzmu, prawidłowych postaw społecznych, poczucia obowiązku obywatelskiego. Miesięcznik był też miejscem, w którym uczniowie mogli zadebiutować jako poeci, prozaicy czy reporterzy. Pismo poprzez organizację licznych konkursów literackich było ciągle otwarte dla nowych autorów. Cały czas poszukiwano nowych utalentowanych redaktorów. Trzeba też zauważyć, że miesięcznik redagowała kadra, w skład której wchodzili uczniowie wielu szkół, co sprzyjało integracji młodzieży z różnych środowisk, co sprzyjało poszerzaniu horyzontów i łamało bariery o charakterze społecznym. „Młodzi Idą...” to bardzo wartościowe przedsięwzięcie szkół zagłębiowskich w dwudziestoleciu międzywojennym.

${ }^{153}$ Redakcja mówi..., tamże, nr 3, s. 19-20.

154 Redakcja mówi..., tamże, nr 5, s. 20. 